\title{
Cardioprotective potential of Korean Red Ginseng extract on isoproterenol-induced cardiac injury in rats
}

\author{
Kyu Hee Lim ${ }^{1}$, Dukhwan Ko ${ }^{2}$, and Jong-Hoon Kim ${ }^{1 *}$ \\ ${ }^{1}$ Department of Veterinary Physiology, College of Veterinary Medicine, Biosafety Research Institute, \\ Chonbuk National University, Jeonju 561-756, Korea \\ ${ }^{2}$ Department of Orthopaedic Surgery, Medical School, Konkuk University, Chungju, 380-701, Korea
}

The present study was designed to investigate the cardioprotective effects of Korean Red Ginseng extract (KRG) on isoproterenol (ISO)-induced cardiac injury in rats, particularly in regards to electrocardiographic changes, hemodynamics, cardiac function, serum cardiac enzymes, components of the myocardial antioxidant defense system, as well as inflammatory markers and histopathological changes in heart tissue. ISO $(150 \mathrm{mg} / \mathrm{kg}$, subcutaneous, two doses administered at 24-hour intervals) treatment induced significant decreases in P waves and QRS complexes $(p<0.01)$, as well as a significant increase in ST segments. Moreover, ISO-treated rats exhibited decreases in left-ventricular systolic pressure, maximal rate of developed left ventricular pressure $\left(+\mathrm{dP} / \mathrm{dt}_{\max }\right)$ and minimal rate of developed left ventricular pressure $\left(-\mathrm{dP}_{\mathrm{dt}} \mathrm{tax}_{\max }\right)$, in addition to significant increases in lactate dehydrogenase, aspartate transaminase, alanine transaminase and creatine kinase activity. Heart rate, however, was not significantly altered. And the activities of superoxide dismutase, catalase and glutathione peroxidase were decreased, whereas the activity of malondialdehyde was increased in the ISO-treated group. ISO-treated group also showed increased caspase-3 level, release of inflammatory markers and neutrophil infiltration in heart tissue. KRG pretreatment ( 250 and $500 \mathrm{mg} / \mathrm{kg}$, respectively) significantly ameliorated almost all of the parameters of heart failure and myocardial injury induced by ISO. The protective effect of KRG on ISO-induced cardiac injury was further confirmed by histopathological study. In this regard, ISO treatment induced fewer morphological changes in rats pretreated with 250 or $500 \mathrm{mg} / \mathrm{kg}$ of KRG. Compared with the control group, all indexes in rats administered KRG $(500 \mathrm{mg} / \mathrm{kg}$ ) alone were unaltered $(p>0.05)$. Our results suggest that KRG significantly protects against cardiac injury and ISO-induced cardiac infarction by bolstering antioxidant action in myocardial tissue.

Keywords: Panax ginseng, Isoproterenol, Cardiac ischemia, Hemodynamics, Myocardial preservation

\section{INTRODUCTION}

Myocardial infarction (MI) is a common symptom of cardiac ischemia, and occurs when cardiac ischemia surpasses a critical threshold, resulting in irreversible myocardial damage [1]. Although with improved clinical care and greater public awareness, MI remains the leading cause of death worldwide [2]. According to the World Health Organization, it will be the major cause of

cC This is an Open Access article distributed under the terms of the Creative Commons Attribution Non-Commercial License (http://creativecommons.org/licenses/by-nc/3.0/) which permits unrestricted non-commercial use, distribution, and reproduction in any medium, provided the original work is properly cited. death in the world by the year 2020 [3]. It is well known that MI leads to the generation of oxygen derived free radicals in the heart, often leading to reactions which contribute to cardiac cell death [4]. And there is increasing production of reactive oxygen species (ROS) such as superoxide anion and hydroxyl radicals, bringing about MI by oxidative injury of cell membrane lipids, proteins,

Edited by Man-Hee Rhee, Kyungpook National University, Korea

Received 30 Oct. 2012, Revised 14 Jan. 2013, Accepted 14 Jan. 2013

*Corresponding author

E-mail: jhkim1@chonbuk.ac.kr

Tel: +82-63-270-2563, Fax: +82-63-270-3780 
and DNA [5]. Hence, therapeutic intervention via suppression of ROS generation or enhancement of endogenous antioxidant enzymes may limit the infarct size and attenuate myocardial dysfunction [6].

Isoproterenol (ISO), a synthetic $\beta$-adrenoceptor agonist, has been found to induce cardiac infarction in rats by disrupting the equilibrium between production of free radicals and the myocardial antioxidant defense system $[7,8]$. Among the various mechanisms of ISO-induced toxicity in the heart, generation of toxic free radicals by oxidation of catecholamines has been shown to play an important role in inducing cardiac injury.

Panax ginseng Meyer is widely used as a traditional herbal medicine, and exhibits multi-functional activities such as antioxidant, anti-inflammatory and anti-aging potencies [9]. Commercially available ginseng is classified into two types. The first type has been subjected to steaming and drying, known as red ginseng (RG), and the second type, which has been subjected to air drying only, is known as white ginseng (WG). In this regard, Yamabe et al. [10] reported that the free radical scavenging activities in ginseng are increased by heating processes. Clinically, it is well known that RG offers more potent effects than WG, and therefore, is used more often in treating heart diseases.

Therefore, in present study, we investigated the protective effects of Korean RG extract (KRG) on ISO-induced cardiac injury in rats. We studied the possible mechanism of its efficacy by studying the electrocardiographic changes, biochemical cardiac markers, and antioxidant parameters, hemodynamics, apoptosis, inflammatory markers, and histopathological changes.

\section{MATERIALS AND METHODS}

\section{Korean Red Ginseng extracts}

KRG manufactured by Korea Ginseng Corporation (Seoul, Korea) were used in all experiments. KRG was made by steaming fresh roots of 6-year-old $P$. ginseng plants at $90^{\circ} \mathrm{C}$ to $100^{\circ} \mathrm{C}$ for $3 \mathrm{~h}$ and subsequent drying at $50^{\circ} \mathrm{C}$ to $80^{\circ} \mathrm{C}$. $\mathrm{KRG}$ was extracted seven times with distilled water at $85^{\circ} \mathrm{C}$ for $8 \mathrm{~h}$ followed by cooling. $\mathrm{KRG}$ contained $0.52 \mathrm{mg} / \mathrm{g}$ of major ginsenoside- $\mathrm{Rg} 1,4.03 \mathrm{mg} /$ $\mathrm{g}$ of $-\mathrm{Rb} 1,2.89 \mathrm{mg} / \mathrm{g}$ of $-\mathrm{Rg} 3(\mathrm{~s}), 1.18 \mathrm{mg} / \mathrm{g}$ of $-\mathrm{Re}, 1.98$ $\mathrm{mg} / \mathrm{g}$ of $-\mathrm{Rc}, 1.97 \mathrm{mg} / \mathrm{g}$ of $-\mathrm{Rb} 2,1.51 \mathrm{mg} / \mathrm{g}$ of $-\mathrm{Rd}$, and other minor ginsenosides. ISO and all other agents were obtained from Sigma (St. Louis, MO, USA). KRG was dissolved in tap water to concentrations of 250 and 500 $\mathrm{mg} / \mathrm{kg}$ for KRG treatments.

\section{Animals}

The study was conducted on 50 mature, male, Wistar strain albino rats weighing $200 \pm 15 \mathrm{~g}$. All animals were obtained from Japan SLC (Shizuoka, Japan). The rats were housed in colony cages (three to four rats per cage) at an ambient temperature of $25 \pm 2^{\circ} \mathrm{C}$ with alternating 12 $\mathrm{h}$ cycles of light and dark. Rats had free access to standard food and water ad libitum for $3 \mathrm{~d}$ to adjust them to the environment. The Principles of Laboratory Animal Care were followed according to the Guidelines for Institutional Animal Care and Use Committees of Chonbuk National University (Jeonju, Korea).

\section{Experimental protocols}

Rats were injected with two doses of ISO dissolved in normal saline $(150 \mathrm{mg} / \mathrm{kg}$, s.c.) at an interval of $24 \mathrm{~h}$ to induce experimental MI [11]. Animals were sacrificed $48 \mathrm{~h}$ after observation of the first ISO-induced MI. For the experiments, animals were divided into five groups ( $n=10$, each group, respectively). The normal control group was administered with physiological saline for $7 \mathrm{~d}$. In the KRG alone group, rats were orally administered with a $500 \mathrm{mg} / \mathrm{kg}$ dose of KRG once a day for $7 \mathrm{~d}$ as a sham control. In the ISO control group, rats were administered with physiological saline for $7 \mathrm{~d}$ and injected with ISO $(150 \mathrm{mg} / \mathrm{kg}$, s.c. injection administered twice at a 24-hour interval) beginning on the 7th day. In the 250 and $500 \mathrm{mg} / \mathrm{kg} \mathrm{KRG}$ pretreatment groups, rats were pretreated with KRG (250 and $500 \mathrm{mg} / \mathrm{kg}$; gastric gavages, respectively) for $7 \mathrm{~d}$, and on the 7th day, subcutaneously injected with two doses of $150 \mathrm{mg} / \mathrm{kg}$ of ISO at a 24-hour interval. The pretreatment dose of KRG was selected following preliminary testing of a variety of doses (Fig. 1).

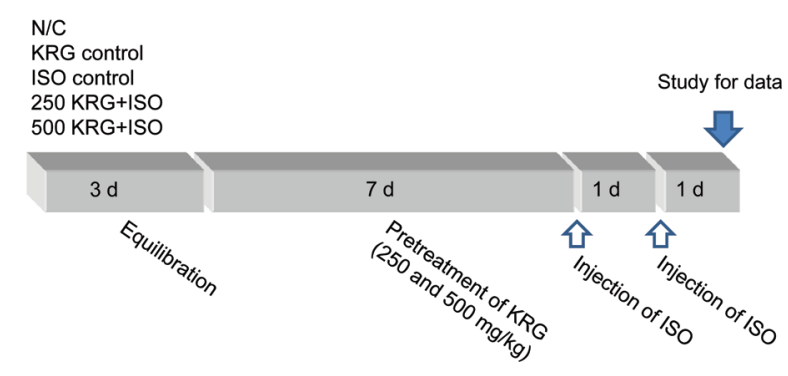

Fig. 1. Experimental protocol. All experimental groups began with a 3-day equilibration, and divided into the normal control (N/C) group, the Korean Red Ginseng extract (KRG) control, isoproterenol (ISO) control, $250 \mathrm{mg} / \mathrm{kg} \mathrm{KRG}$ pretreatment and $500 \mathrm{mg} / \mathrm{kg} \mathrm{KRG} \mathrm{pretreat-}$ ment group. In KRG pretreated group, the animals were pretreated with 250 and $500 \mathrm{mg} / \mathrm{kg}$ of KRG for $7 \mathrm{~d}$. And, ISO was injected subcutaneously to rats $(150 \mathrm{mg} / \mathrm{kg})$ daily for 2 consecutive days to induce experimental myocardial infarction. 


\section{Hemodynamics parameters}

At the end of the above experiments, the rats were anesthetized with urethane ( $1 \mathrm{~g} / \mathrm{kg}$ intraperitoneally), and electrodes were inserted under the skin for the limb lead at position II. Electrocardiograph (ECG) was then recorded. Elevation and decline of P waves, QRS complexes, and ST segments in each group were studied. And then, to evaluate left ventricular function of the heart, a catheter filled with heparin saline $(500 \mathrm{U} / \mathrm{mL})$ was inserted into the left ventricle, and left-ventricular systolic pressure (LVSP), as well as maximal and minimal rates of developed left ventricular pressure $\left(+\mathrm{dP}^{\mathrm{d}} / \mathrm{dt}_{\max }\right.$ and $-\mathrm{dP} /$ $\mathrm{dt}_{\max }$, respectively) were measured by a BL-420E monitor system.

\section{Determination of body weighting and cardiac injury}

After recording the ECG and hemodynamics, the animals were weighed and sacrificed. And blood sample was collected. Serum was separated from each sample and used for biochemical analysis. Hearts were excised and weighted. Heart weight to body weight ratio was calculated by dividing the heart weight $(\mathrm{g})$ by body weight $(\mathrm{g})$ and multiplying by 100 [12]. The hearts were stored at $-80^{\circ} \mathrm{C}$ until ready for further use and analysis. The specific marker enzymes for MI such as lactate dehydrogenase (LDH) [13], aspartate transaminase (AST) [14], alanine transaminase (ALT) [14], and creatine kinase-MB (CK-MB) [15] were measured as previously described. In serum, increased LDH, AST, ALT, and CKMB levels were considered as indicative of oxidative stress. For antioxidant parameters, heart tissue was homogenized in chilled Tris- $\mathrm{HCl}$ buffer $(0.1 \mathrm{M})$ at a $\mathrm{pH}$ of 7.4. The homogenate was then centrifuged at $10,000 \times \mathrm{g}$ at $0^{\circ} \mathrm{C}$ using a Remi C-24 high speed cooling centrifuge. The clear supernatant was used for assay of endogenous antiperoxidative enzymes such as superoxide dismutase (SOD), catalase (CAT), and glutathione peroxidase (GSH-Px). SOD was determined by the method previously described by Mishra and Fridovich [16]. CAT was estimated by the method described by Aebi [17]. GSHPx was estimated by the methods described by Rotruck et al. [18]. Malondialdehyde (MDA), indicative of lipid peroxidation formation, was assessed according to its absorbencies by spectrophotometry [19].

\section{Determination of caspase-3 and tumor necrosis factor-a}

Caspase-3 protein levels were determined by western blotting as previously described [20]. Briefly, $40 \mu \mathrm{g}$ of protein was separated by $8 \%$ SDS-polyacrylamide gel electrophoresis and transferred to polyvinylidene difluoride membranes. The membranes were incubated with the indicated primary antibody, followed by secondary antibody conjugated with horseradish peroxidase. Protein bands were detected using an enhanced chemiluminescence Western blotting detection kit and then exposed to X-ray film. Caspase-3 levels were normalized by comparison to $\beta$-actin $(63 \mathrm{kDa})$. For tumor necrosis factor- $\alpha$ (TNF- $\alpha$ ) assay, left ventricle samples were collected and immediately stored at $-70^{\circ} \mathrm{C}$ until ready for assay as previously described [21]. In brief, the tissue was homogenized in RIPA ( $150 \mathrm{mmol} / \mathrm{L} \mathrm{NaCl}, 0.1 \% \mathrm{SDS}, 0.5 \%$ sodium deoxycholate, $1 \% \mathrm{NP}-40,50 \mathrm{mmol} / \mathrm{L}$ Tris, $\mathrm{pH}$ 7.4, $20 \mathrm{mmol} / \mathrm{L} \mathrm{NaF}, 2 \mathrm{mmol} / \mathrm{L}$ EGTA, $0.5 \%$ levamisole, $1 \mathrm{mmol} / \mathrm{L} \mathrm{NaVO} 4,1 \mu \mathrm{g} / \mathrm{mL}$ leupeptin) containing 1 $\mathrm{mmol} / \mathrm{L}$ of PMSF. Supernatants were obtained by centrifugation $\left(18,000 \times g, 15 \mathrm{~min}, 4^{\circ} \mathrm{C}\right)$. TNF- $\alpha$ level in the supernatants was determined using an ELISA kit (R\&D Systems, Minneapolis, MN, USA). The final results were expressed as $\mathrm{pg} / \mathrm{mg}$ of protein.

\section{Myeloperoxidase assay}

To quantify myocardial neutrophil infiltration, the activity of myeloperoxidase (MPO), an abundant enzyme found in neutrophils, was assessed using a modified method [22]. Myocardial tissue was homogenized in 50 $\mathrm{mM} \mathrm{K}_{2} \mathrm{HPO}_{4}$ buffer (pH 6). In brief, $40 \mu \mathrm{L}$ of sample were mixed with $960 \mu \mathrm{L}$ of $50 \mathrm{mM}$ phosphate buffer $(\mathrm{pH}$ 6), containing $0.167 \mathrm{mg} / \mathrm{mL}$ of O-dianisidine dihydrochloride and $0.0005 \% \mathrm{H}_{2} \mathrm{O}_{2}$. Changes in absorbance at $460 \mathrm{~nm}$ were studied by a spectrophotometer. One unit of enzyme activity was considered equal to the amount of MPO absorbance measured at $460 \mathrm{~nm}$ for $3 \mathrm{~min}$. MPO activity data weree presented as $\mathrm{U} / \mathrm{mg}$ of tissue.

\section{Histopathological examination}

For histopathological study, tissues were processed by a previously described method [23]. Briefly, at the end of the hemodynamics evaluation, cardiac tissues were fixed in $10 \%$ formalin, processed, and embedded in paraffin wax. Paraffin sections $(4 \mu \mathrm{m})$ were cut on glass slides, and stained with hematoxylin and eosin (H\&E), and examined under a light microscope by a pathologist blinded to the groups studied

\section{Statistical analysis}

All the values were expressed as mean \pm SEM. Statistical significance between more than two groups was tested using one-way ANOVA followed by unpaired two-tailed Student's $t$-test as appropriate using computer 
Table 1. Heart weight, body weigh and heart weight/body weight ratio

\begin{tabular}{lccc}
\hline Group $(n=10)$ & Body weight $(\mathrm{g})$ & Heart weight $(\mathrm{g})$ & Heart weight/body weight ratio \\
\hline N/C & $209.8 \pm 9.6$ & $0.61 \pm 0.05$ & $0.291 \pm 0.004$ \\
KRG control & $211.5 \pm 10.4$ & $0.64 \pm 0.04$ & $0.303 \pm 0.005$ \\
ISO control & $202.9 \pm 8.5$ & $0.92 \pm 0.09$ & $0.430 \pm 0.007$ \\
250KRG+ISO & $205.7 \pm 12.1^{1)}$ & $0.79 \pm 0.07^{2)}$ & $0.398 \pm 0.015^{2)}$ \\
500 KRG+ISO & $207.3 \pm 9.1^{1)}$ & $0.76 \pm 0.04^{3)}$ & $0.357 \pm 0.011^{3)}$ \\
\hline
\end{tabular}

Results are expressed as the mean $\pm S D$ in each group.

N/C, normal control; KRG, Korean Red Ginseng extract; ISO, isoproterenol.

1) No significant from ISO control.

2) Significantly different $(p<0.05)$ from ISO control.

${ }^{3)}$ Significantly different $(p<0.01)$ from ISO control.
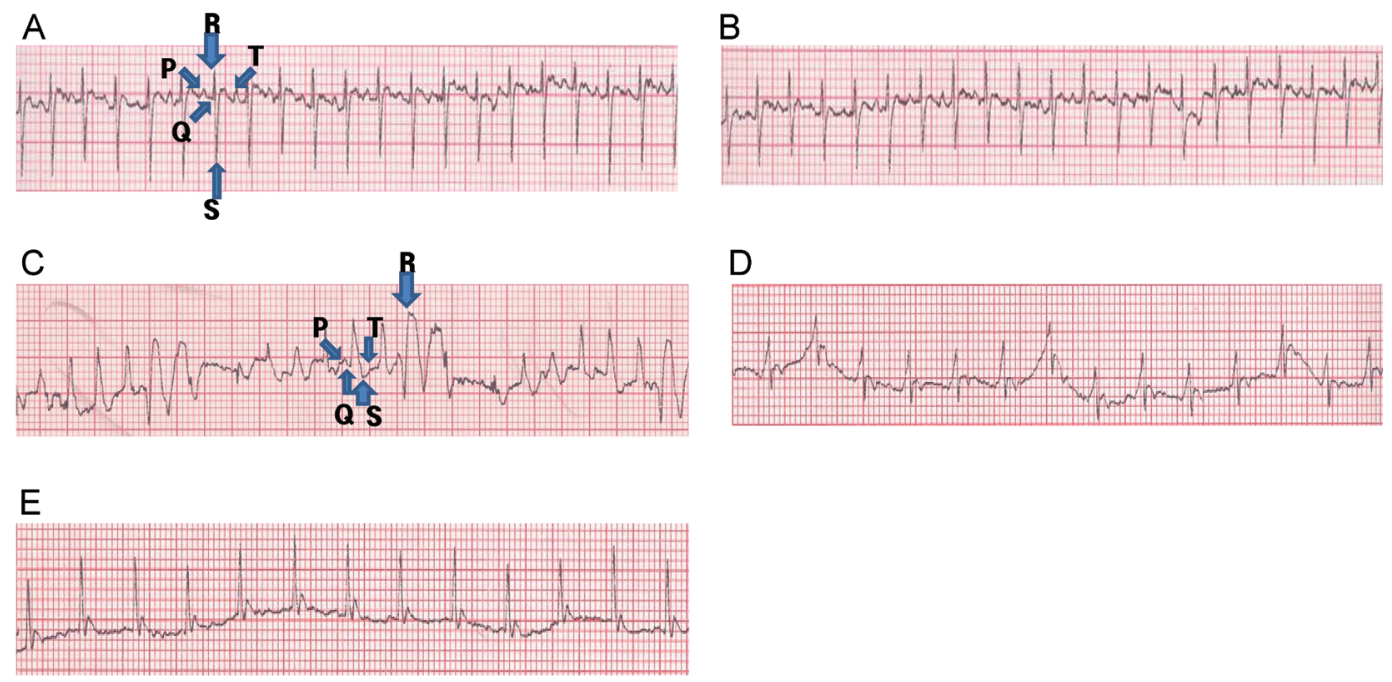

Fig. 2. Effect of Korean Red Ginseng extract (KRG) pretreatment on electrocardiographic pattern (A) normal control, (B) KRG control, (C) iso-

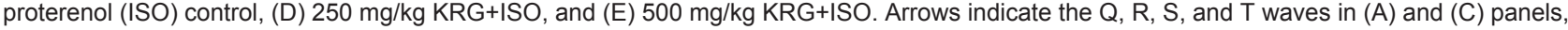
although it was not shown in (B, D, and E) panels. Electrocardiogram was recorded from limb leads II with recorder speed $50 \mathrm{~ms} / \mathrm{div}$ in each group.

based fitting program (Prism; Graphpad, San Diego, CA, USA). Differences were considered to be statistically significant when $p<0.05$.

\section{RESULTS}

\section{Body weight and heart weight}

The effects of KRG pretreatment on heart weight, body weight, and heart weight to body weight ratio are shown in Table 1. There was no significant difference in body weight among the groups observed, although ISOtreated animals tended to show a slight decrease in body weight. Heart weight and heart weight to body weight ratio were significantly increased in the ISO-treated alone group. KRG pretreatment significantly improved heart weight and the heart weight to body weight ratio $(p<0.05$ and $p<0.001)$ (Table 1).

\section{Effect of Korean Red Ginseng extract on hemody- namic parameters}

The ECG patterns of normal and experimental group rats are shown in Fig. 2 and Table 2. Normal control and KRG alone group rats showed normal patterns of ECG, whereas ISO-treated alone rats showed a significant increase in ST segments, as compared to the normal control group, indicative of cardiac infarction (Fig. 2 and Table 2). ISO-treated alone group rats also exhibited pathological Q waves indicative of cardiac infarction. Moreover, a significant decrease in $\mathrm{P}$ waves and QRS complexes was observed in ISO-treated alone group rats, as compared to normal control rats $(p<0.05$ and $p<0.01)$ (Table 2). Furthermore, KRG pretreatment ( 250 and $500 \mathrm{mg}$ / $\mathrm{kg}$ ) resulted in a significant increase in $\mathrm{P}$ waves and QRS complexes compared to ISO-treated rats $(p<0.05$ and $p<0.01$ ) (Table 2). KRG pretreatment rats also showed a 
Table 2. Effect of KRG pretreatment on electrocardiographic parameters

\begin{tabular}{lcccc}
\hline Group $(n=10)$ & P wave $(\mathrm{s})$ & QRS complex $(\mathrm{s})$ & ST segment $(\mathrm{mV})$ & R-amplitude $(\mathrm{mV})$ \\
\hline N/C & $0.029 \pm 0.0022$ & $0.045 \pm 0.0022$ & $0.237 \pm 0.015$ & $0.932 \pm 0.034$ \\
KRG control & $0.031 \pm 0.0024$ & $0.044 \pm 0.0019$ & $0.229 \pm 0.022$ & $0.965 \pm 0.041$ \\
ISO control & $0.015 \pm 0.0015$ & $0.027 \pm 0.0031$ & $0.394 \pm 0.045$ & $0.742 \pm 0.068$ \\
250KRG+ISO & $0.019 \pm 0.0047^{1)}$ & $0.032 \pm 0.0057^{1)}$ & $0.306 \pm 0.059^{1)}$ & $0.862 \pm 0.071^{1)}$ \\
500KRG+ISO & $0.023 \pm 0.0032^{2)}$ & $0.036 \pm 0.0043^{2)}$ & $0.276 \pm 0.038^{2)}$ & $0.914 \pm 0.043^{2)}$ \\
\hline
\end{tabular}

Results are expressed as the mean $\pm S D$ in each group.

KRG, Korean Red Ginseng extract; N/C, normal control; ISO, isoproterenol.

1) Significantly different $(p<0.05)$ from ISO control.

${ }^{2)}$ Significantly different $(p<0.01)$ from ISO control.

Table 3. Effect of KRG pretreatment on hemodynamics functions

\begin{tabular}{lcccc}
\hline Group $(n=10)$ & Heart rate $(\mathrm{bpm})$ & LVSP $(\mathrm{mmHg})$ & $\mathrm{LVdP} / \mathrm{dt}_{\max }(\mathrm{mmHg} / \mathrm{s})$ & $\mathrm{LVdP} / \mathrm{dt}_{\min }(\mathrm{mmHg} / \mathrm{s})$ \\
\hline N/C & $376.3 \pm 36.75$ & $115.43 \pm 15.56$ & $5874.62 \pm 775.8$ & $4485.79 \pm 569.53$ \\
KRG (per se) & $384.31 \pm 29.63$ & $118.76 \pm 16.75$ & $5796.31 \pm 496.5$ & $4586.22 \pm 668.41$ \\
ISO & $363.72 \pm 37.43$ & $87.54 \pm 18.76$ & $3549.84 \pm 785.76$ & $2756.78 \pm 853.85$ \\
250KRG+ISO & $369.74 \pm 42.15$ & $94.85 \pm 22.73^{1)}$ & $4694.81 \pm 856.72^{1)}$ & $3854.32 \pm 634.72^{1)}$ \\
500 KRG+ISO & $371.62 \pm 35.73$ & $105.6 \pm 19.75^{2)}$ & $4986.37 \pm 673.4^{2)}$ & $4037.81 \pm 569.54^{2)}$ \\
\hline
\end{tabular}

Results are expressed as the mean $\pm S D$ in each group.

KRG, Korean Red ginseng extract; LVSP, left ventricular systolic pressure; LVdP/dt ${ }_{\max }$, maximal left ventricle developed pressure; LVdP/dt ${ }_{\min }$ minimal left ventricle developed pressure; N/C, normal control; ISO, isoproterenol.

1) Significantly different $(p<0.05)$ from ISO control.

${ }^{2)}$ Significantly different $(p<0.01)$ from ISO control.

A

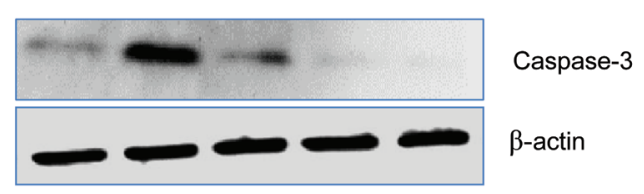

B

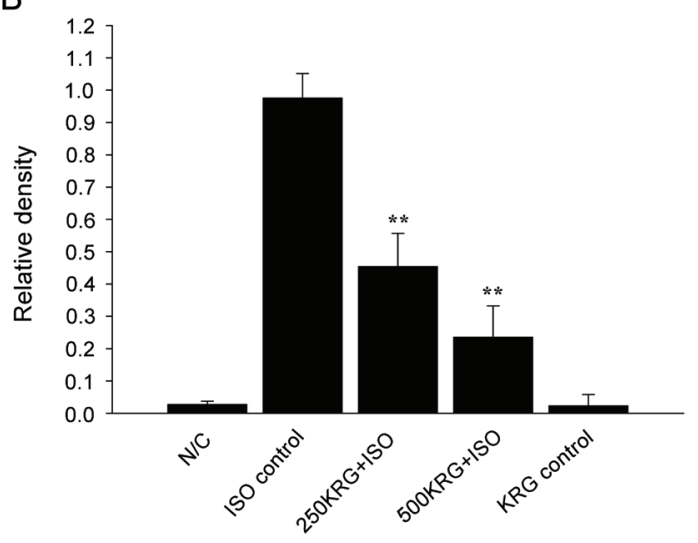

Fig. 3. Effect of Korean Red Ginseng extract (KRG) on caspase-3. Cleaved caspase- 3 was determined by Western blotting methods (A). Densitometric analysis of each protein was shown (B). Results are representative of three independent experiments. N/C, normal control; KRG control, isoproterenol (ISO) control, ISO injection only without KRG pretreatment; $250 \mathrm{KRG}+$ ISO, KRG pretreatment at the dose of $250 \mathrm{mg} / \mathrm{kg}$ for $7 \mathrm{~d} ; 500 \mathrm{KRG}+\mathrm{ISO}$, KRG pretreatment at the dose of $500 \mathrm{mg} / \mathrm{kg}$ for $7 \mathrm{~d} .{ }^{* *} p<0.01$. significant decrease in ST segments as compared to ISOtreated alone group rats (Fig. 2 and Table 2).

Compared with rats of the normal control group, ISOtreated alone group rats showed decreased left ventricular dysfunction as indicated by significant decreases in LVSP, $+\mathrm{dP}^{\mathrm{d}} / \mathrm{dt}_{\max }$, and $-\mathrm{dP} / \mathrm{dt}_{\max }$ parameters. Heart rate, however, was not significantly altered $(p>0.05)$. Pretreatment of 250 and $500 \mathrm{mg} / \mathrm{kg}$ of KRG improved these cardiac functions, compared to ISO-treated alone group rats (Table 3).

\section{Effect of Korean Red Ginseng extract on cardiac enzymes and antioxidant}

The cardioprotective effects of KRG $(250 \mathrm{mg} / \mathrm{kg}$ and $500 \mathrm{mg} / \mathrm{kg}$ ) on serum marker enzyme (LDH, AST, ALT, and CK-MB) levels are summarized in Table 4. Among the results, serum marker enzymes levels were significantly increased in ISO-treated alone group rats $(p<0.01)$, whereas KRG pretreatment significantly reversed these elevated levels $(p<0.05$ for $250 \mathrm{mg} / \mathrm{kg}$ of $\mathrm{KRG}$ and $p<0.01$ for $500 \mathrm{mg} / \mathrm{kg}$ of KRG) (Table 4). The antioxidant enzyme activities of SOD, CAT, GSH-Px, and MDA are shown in Table 5. The antioxidative enzyme activities of SOD, CAT and GSH-Px were significantly decreased in the cardiac tissues of ISO-treated rats, as compared to normal control rats. Moreover, ISO-treated rats exhibited 
Table 4. Effect of KRG pretreatment on cardiac marker enzyme in serum

\begin{tabular}{|c|c|c|c|c|}
\hline Group $(n=10)$ & LDH (IU/L) & AST (U/L) & ALT (U/L) & CK-MB (IU/L) \\
\hline $\mathrm{N} / \mathrm{C}$ & $253.42 \pm 36.84$ & $64.85 \pm 6.73$ & $49.63 \pm 4.84$ & $79.64 \pm 6.56$ \\
\hline KRG control & $267.51 \pm 22.75$ & $67.74 \pm 8.52$ & $48.53 \pm 5.37$ & $81.42 \pm 5.45$ \\
\hline ISO control & $598.9 \pm 64.84$ & $171.56 \pm 15.65$ & $149.75 \pm 9.64$ & $235.71 \pm 29.6$ \\
\hline 250KRG+ISO & $486.47 \pm 54.32^{1)}$ & $146.84 \pm 13.96^{1)}$ & $125.62 \pm 13.37^{1)}$ & $184.3 \pm 31.54^{1)}$ \\
\hline $500 \mathrm{KRG}+\mathrm{ISO}$ & $419.74 \pm 47.63^{2)}$ & $113.56 \pm 14.85^{2)}$ & $95.73 \pm 8.54^{2)}$ & $132.65 \pm 22.79^{2)}$ \\
\hline
\end{tabular}

Results are expressed as the mean \pm SD in each group.

KRG, Korean Red Ginseng extract; LDH, lactate dehydrogenase; AST, aspartate transaminase; ALT, alanine transaminase; CK-MB, creatine kinase-MB; N/C, normal control; ISO, isoproterenol.

1) Significantly different $(p<0.05)$ from ISO control.

2) Significantly different $(p<0.01)$ from ISO control.

Table 5. Effect of KRG pretreatment on antioxidant in heart tissue

\begin{tabular}{|c|c|c|c|c|}
\hline Group $(n=10)$ & $\begin{array}{l}\text { Superoxide dismutase } \\
\text { (U/mg protein) }\end{array}$ & $\begin{array}{c}\text { Catalase } \\
\text { ( } \mu \mathrm{mol} \text { of } \mathrm{H}_{2} \mathrm{O}_{2} \text { consumed/mg protein) }\end{array}$ & $\begin{array}{c}\text { Glutathione peroxidase } \\
\text { ( } \mu \mathrm{mol} \text { of glutathione oxidized/mg protein) }\end{array}$ & $\begin{array}{l}\text { Malondialdehyde } \\
\text { (nmol/mg protein) }\end{array}$ \\
\hline $\mathrm{N} / \mathrm{C}$ & $9.84 \pm 0.92$ & $17.58 \pm 0.85$ & $2.61 \pm 0.12$ & $5.83 \pm 1.22$ \\
\hline KRG control & $9.75 \pm 0.75$ & $16.95 \pm 0.94$ & $2.73 \pm 0.09$ & $5.76 \pm 1.31$ \\
\hline ISO control & $6.32 \pm 1.13$ & $11.43 \pm 1.22$ & $2.17 \pm 0.14$ & $10.02 \pm 1.53$ \\
\hline $250 \mathrm{KRG}+\mathrm{ISO}$ & $7.63 \pm 1.47^{1)}$ & $13.26 \pm 1.54^{1)}$ & $2.35 \pm 0.26^{1)}$ & $8.25 \pm 1.76^{1)}$ \\
\hline $500 \mathrm{KRG}+\mathrm{ISO}$ & $8.76 \pm 1.35^{2)}$ & $14.89 \pm 0.93^{3)}$ & $2.46 \pm 0.19^{2)}$ & $7.29 \pm 1.43^{2)}$ \\
\hline
\end{tabular}

Results are expressed as the mean $\pm S D$ in each group.

KRG, Korean Red Ginseng extract; N/C, normal control; ISO, isoproterenol.

${ }^{1)}$ Significantly no difference compared with ISO control $(p>0.05)$.

2) Significantly different $(p<0.05)$ from ISO control.

${ }^{3)}$ Significantly different $(p<0.01)$ from ISO control.

significant increases in MDA level, a marker of oxidative stress, in heart tissues. Normal rats administrated only $500 \mathrm{mg} / \mathrm{kg}$ of KRG did not show any significant changes, indicating that KRG per se does not exert any adverse effects. KRG pretreatment $(500 \mathrm{mg} / \mathrm{kg}$ for $7 \mathrm{~d}$ ) along with ISO treatment on 7th and 8th day showed significant increases in SOD, CAT, and GSH-Px levels $(p<0.05$ for SOD and GSH-Px, $p<0.01$ for CAT). Additionally, KRG pretreatment $(500 \mathrm{mg} / \mathrm{kg}$ for $7 \mathrm{~d}$ ) in ISO-treated rats significantly decreased the elevated MDA levels, as compared to the ISO-treated alone group $(p<0.01)$ (Table 5). However, pretreatment with $250 \mathrm{mg} / \mathrm{kg}$ of $\mathrm{KRG}$ exerted no significant difference in MDA levels compared to rats of the ISO-treated alone group ( $p>0.05)$ (Table 5).

\section{Effect of Korean Red Ginseng extract on caspase-3 and tumor necrosis factor-a production}

Caspase-3 protein expression was measured to determine whether KRG inhibited apoptosis by regulating the expression of caspase-related proteins in rat hearts. KRG pretreatment for $7 \mathrm{~d}$ (250 and $500 \mathrm{mg} / \mathrm{kg}$ ) significantly decreased caspase- 3 protein levels compared to those in ISO-treated alone group rats ( $p<0.01)$ (Fig. 3). Moreover, normal rats administered only $500 \mathrm{mg} / \mathrm{kg}$ of $\mathrm{KRG}$ did not show any significant change in caspase-3 activity, indicating that KRG does not per se exert any adverse effects (Fig. 3). Heart tissues from normal control and 500 $\mathrm{mg} / \mathrm{kg} \mathrm{KRG}$ treatment alone group rats exhibited lower levels of TNF- $\alpha$ of $569.43 \pm 17.54$ and $584.37 \pm 19.76$ $\mathrm{pg} / \mathrm{mg}$ of protein. Additionally, a significant amount of TNF- $\alpha$ (995.43 $\pm 43.84 \mathrm{pg} / \mathrm{mg}$ protein) was detected in ISO-treated hearts. Pretreatment of KRG at the doses of 250 and $500 \mathrm{mg} / \mathrm{kg}$ for 7 days before ISO treatment led to a significant decrease in the amount of TNF- $\alpha$ produced $(845.62 \pm 83.27 \mathrm{pg} / \mathrm{mL}$ protein for $250 \mathrm{mg} / \mathrm{kg}$ of $\mathrm{KRG}, p<0.05 ; 732.96 \pm 75.92 \mathrm{pg} / \mathrm{mL}$ protein for $500 \mathrm{mg} /$ $\mathrm{kg}$ of $\mathrm{KRG}, p<0.01$ ) (Fig. 4).

\section{Effect of Korean Red Ginseng extract on myeloper- oxidase activity}

ISO-treated alone group rats showed a significant increase in inflammatory markers such as MPO, when compared to normal control group rats (Fig. 5). KRG pretreatment in ISO-treated rats led to a significant decrease in myocardial MPO activity as compared to rats of the ISO-treated alone group ( $p<0.05$ for $250 \mathrm{mg} / \mathrm{kg}$ of $\mathrm{KRG}$ and $p<0.01$ for $500 \mathrm{mg} / \mathrm{kg}$ of KRG) (Fig. 4). Specifically, normal control and $500 \mathrm{mg} / \mathrm{kg}$ of $\mathrm{KRG}$ treated 


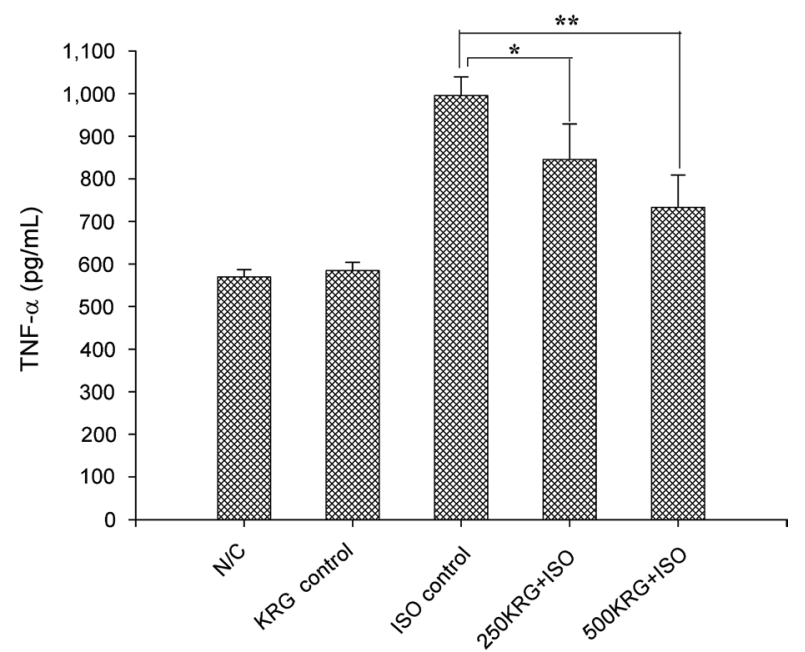

Fig. 4. Effect of Korean Red Ginseng extract (KRG) pretreatment on tissue tumor necrosis factor- $\alpha$ (TNF- $\alpha$ ) levels in isoproterenol (ISO)-induced myocardial infarction in rats. N/C, normal control; KRG control, ISO control, ISO injection only without KRG pretreatment; $250 K R G+I S O, K R G$ pretreatment at the dose of $250 \mathrm{mg} / \mathrm{kg}$ for $7 \mathrm{~d}$; $500 \mathrm{KRG}+$ ISO, KRG pretreatment at the dose of $500 \mathrm{mg} / \mathrm{kg}$ for $7 \mathrm{~d}$. ${ }^{*} p<0.05$ and ${ }^{* *} p<0.01$ as compared to ISO control group.

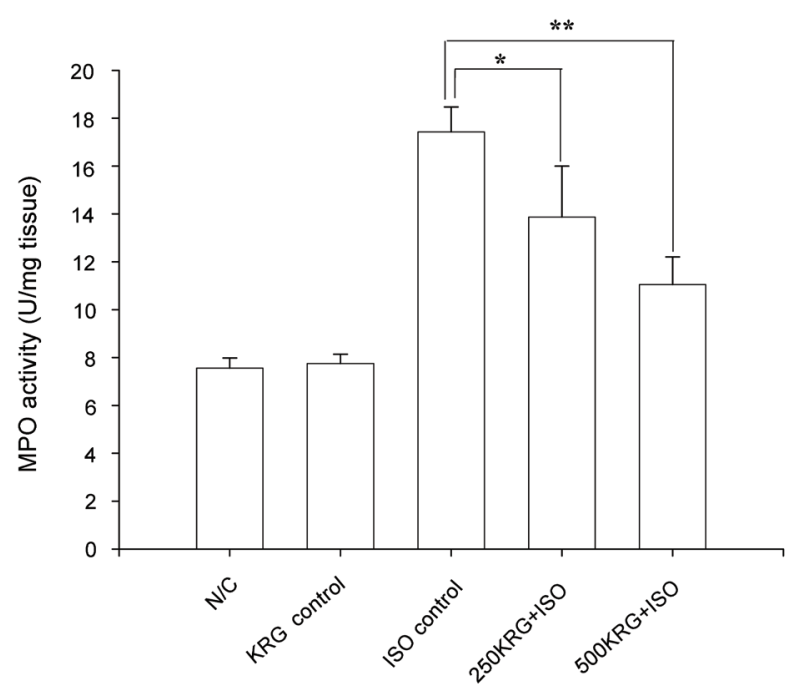

Fig. 5. Effect of Korean Red Ginseng extract (KRG) pretreatment on myeloperoxidase (MPO) activity in the heart in isoproterenol (ISO)-induced myocardial infarction in rats. N/C, normal control; KRG control, ISO control, ISO injection only without KRG pretreatment; $250 \mathrm{KRG}+$ ISO, KRG pretreatment at the dose of $250 \mathrm{mg} / \mathrm{kg}$ for $7 \mathrm{~d}$ $500 K R G+I S O, K R G$ pretreatment at the dose of $500 \mathrm{mg} / \mathrm{kg}$ for $7 \mathrm{~d}$. ${ }^{*} p<0.05$ and ${ }^{* *} p<0.01$ as compared to ISO control group.
A

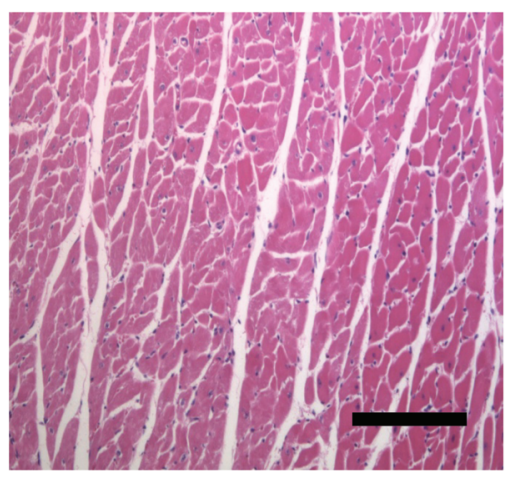

D

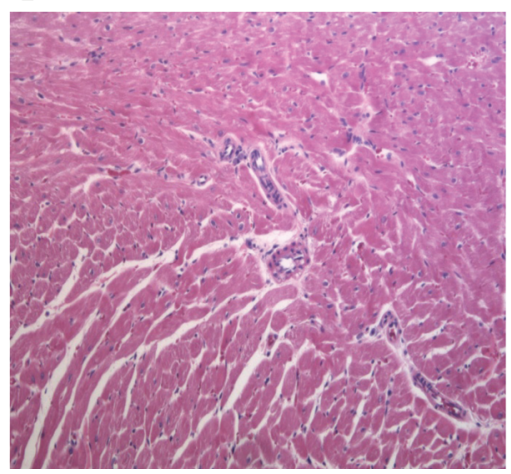

B

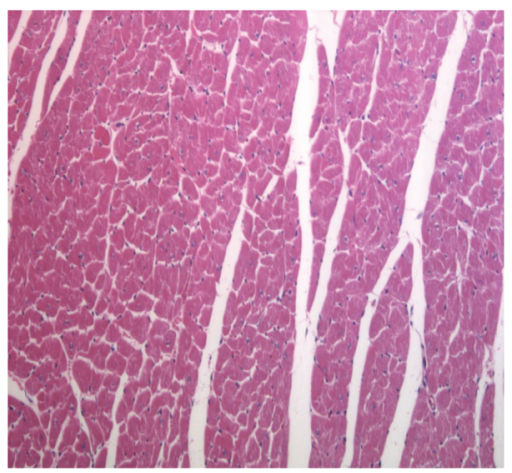

$\mathrm{E}$

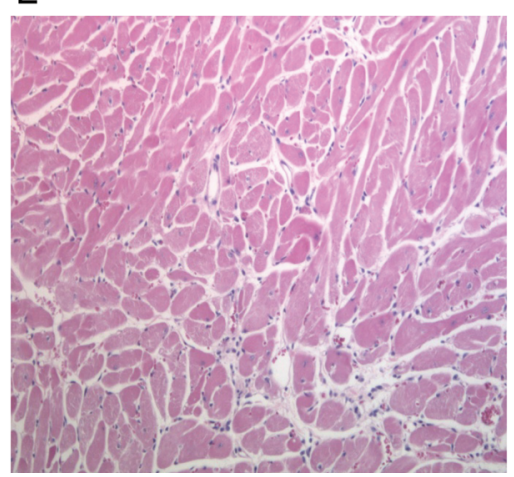

C

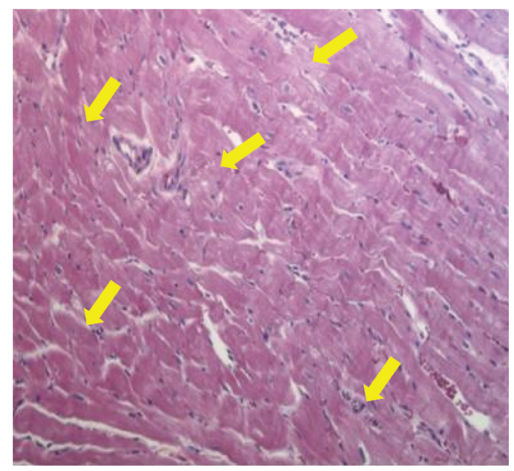

Fig. 6. Effect of Korean Red Ginseng extract (KRG) pretreatment on histopathological changes. Photomicrograph of rat heart in (A) normal control showing normal limits with no edema and inflammatory cells, (B) KRG control showing also normal architecture, (C) isoproterenol (ISO) control showing areas of focal myonecrosis and edema with fibroblastic proliferation as indicated by arrow, (D) $250 \mathrm{mg} / \mathrm{kg} \mathrm{KRG+ISO} \mathrm{showing} \mathrm{de-}$ creased degree of necrosis, edema and less infiltration of inflammatory cells, and (E) $500 \mathrm{mg} / \mathrm{kg} \mathrm{KRG+ISO}$ showing clear reversal of myocardial membrane damage in terms of decreased degree of necrosis and lesser infiltration of inflammatory cells. Heart tissues were stained with hematoxylin and eosin and visualized under light microscope at $\times 100$ magnification. Scale bar, $50 \mu \mathrm{m}$. 
control group rats demonstrated MPO activity levels of $7.56 \pm 0.42$ and $7.75 \pm 0.39 \mathrm{U} / \mathrm{mg}$ of tissue, whereas a significant increase was detected in ISO-treated alone group rats (17.43 $\pm 1.04 \mathrm{U} / \mathrm{mg}$ in ISO-treated heart tissue). KRG pretreatment ( 250 and $500 \mathrm{mg} / \mathrm{kg}$ for $7 \mathrm{~d}$ ) led to a significant decrease in elevated MPO activity in ISOtreated rats $(13.87 \pm 2.13 \mathrm{U} / \mathrm{mg}$ heart tissue for $250 \mathrm{mg} / \mathrm{kg}$ of KRG and $11.05 \pm 1.15 \mathrm{U} / \mathrm{mg}$ heart tissue for $500 \mathrm{mg} / \mathrm{kg}$ of KRG) (Fig. 5).

\section{Histopathological examination}

On H\&E light micrographs for histopathological study, normal control group rats showed normal architecture (Fig. 6A). In ISO-treated alone group rats, many myocardial structure disorders of muscle fibers as well as infiltration of acute inflammatory cells, along with extravasation of red blood cells, were observed. Other structural changes included interstitial edema and the appearance of vacuoles in ISO-treated alone group rats (Fig. 6C). KRG pretreatment (250 and $500 \mathrm{mg} / \mathrm{kg}$, respectively) led to marked decrease in endocardial necrosis and leukocyte infiltration compared to the ISO-treated alone group (Fig. $6 \mathrm{D}, \mathrm{E})$. Heart tissues from rats treated with $500 \mathrm{mg} / \mathrm{kg}$ of KRG alone exhibited similar architecture to that of normal control hearts (Fig. 6B).

\section{DISCUSSION}

ISO-induced cardiac ischemia is known to exhibit many metabolic and morphologic abnormalities in experimental animal models, similar to those in humans [24]. In present study, following ISO treatment, heart weight was significantly increased while body weight remained unchanged, resulting in an increase in heart weight to body weight ratio. The observed increase in heart weight might be attributed to increased water content and edematous conditions in intramuscular space [25]. It is well known that a $1 \%$ increase in myocardial water content could result in a $10 \%$ decrease in myocardial function [26]. KRG pretreatment inhibited the observed increase in heart weight to body weight ratio due to ISO injection, suggesting KRG protects against cardiac ischemia. This also could have resulted from decreases in the water content of cardiac tissue. In ECG, ISO alone group showed decreases in $\mathrm{P}$ wave intensity and QRS complexes. These changes could be due to a loss of cardiac cell membrane [27]. ISO alone group also showed increases in STsegments. Such increases were previously shown to be representative of potential differences in the border between ischemic and non-ischemic conditions and loss of cardiac cell membrane function [12]. KRG significantly inhibited the observed pathological ECG abnormalities, suggesting KRG exerts a protective effect in cardiac cell membranes. Also, ISO led to cardiac dysfunction, characterized by decreases in left ventricular systolic pressure and $\pm \mathrm{dp} / \mathrm{dt}$ [28]. However, KRG significantly inhibited changes in left ventricular systolic pressure and \pm dp/dt. The results suggested that KRG alleviates cardiac injury induced by ISO and ameliorates abnormal heart function. Cardiac cells contain marker enzymes, such as LDH, AST, ALT, and CK-MB. Our results showed that ISO led to a significant increase in LDH, AST, ALT, and CKMB activity. However, KRG pretreatment (250 and 500 $\mathrm{mg} / \mathrm{kg}$ ) significantly inhibited the ISO-induced increases in these enzymes, indicating that KRG ameliorates ISOinduced cardiac injury. In previous studies, ISO treatment caused severe oxidative stress in rat hearts [7]. In this regard, increases in reactive oxygen species or depletion of antioxidants may induce increased oxidative stress and, thereby, MI [29]. Free radical scavenging enzymes such as SOD, CAT, and GSH-Px [29] are the main defense against oxidative stress, by eliminating oxygen radicals, such as superoxide $\left(. \mathrm{O}^{2-}\right)$ and hydrogen peroxide $\left(\mathrm{H}_{2} \mathrm{O}_{2}\right)$, and by preventing the production of hydroxyl radicals (.OH). Previously, KRG was shown to exert protective effects as an antioxidant [30]. In this respect, in the present study, we demonstrated that the decreased activities of SOD, CAT, and GSH-Px in the ISO alone group were significantly increased by KRG (Table 5). These results suggested that KRG could bolster the myocardial antioxidative defense system against oxidative stress. Additionally, lipid peroxidation has been shown to be associated with heart injury severity, and has been linked with abnormal cell membrane function and enzyme inactivation [31]. MDA is a lipid peroxidant end product, and increased MDA level may contribute to increased free radical production or decreased antioxidant activity [32]. In previous studies, cardiac infarction induced by ISO was suggested to result from radical-related lipid peroxidation [32]. In this study, KRG decreased elevated MDA levels by ISO. The observed decrease in MDA levels in the heart might be due to the increased activities of SOD, CAT, and GSH-Px after KRG pretreatment. It may be possible that the free radicals induced by ISO were effectively scavenged thereby, suggesting a cardioprotective effect for KRG. In the present study, we also observed a significant increase in caspase- 3 activity, indicative of apoptosis, and TNF- $\alpha$, an inflammatory cytokine, in the hearts of ISO alone group. TNF- $\alpha$ reportedly plays an important role in myocardial injury [33]. 
As shown in this study, KRG suppressed caspase-3 activity and TNF- $\alpha$ protein production, further demonstrating the cardioprotective effects of KRG. MPO, an enzyme related to the azurophilic granules of neutrophils, can be measured as an indicator of neutrophil infiltration into inflamed tissue [34]. Accordingly, ISO treatment induced a significant increase in MPO levels, indicative of necrosis induced inflammation of cardiac tissue. Nevertheless, KRG significant decreased the elevated MPO levels, indicating that $\mathrm{KRG}$ inhibits neutrophil infiltration to cardiac tissue. In the present study, the left ventricles of ISO alone group showed widespread myocardial structure abnormalities and endocardial necrosis related to cardiac tissue edema, myofibrillar fracture, and infiltration of neutrophils. However, KRG significantly inhibited the ISO-induced cardiac injury. These results further confirmed the cardioprotective effects of KRG.

Until now, more than 30 different ginsenosides from KRG have been isolated and characterized, and these ginsenosides are known to have many pharmacologic effects. It is well known that ginsenosides exert their antioxidant ability by increasing antioxidant enzymes and acting as a free-radical scavenger such as Rg1, Rg3, $\mathrm{Re}, \mathrm{Rd}, \mathrm{Rh} 2$, and $\mathrm{Rg} 2$ [35-39]. Among the many ginsenosides, it appears that $\mathrm{Rb} 1$ and $\mathrm{Rg} 1$ possess more potent antioxidant activity [40]. In present study, ginsenoside $\mathrm{Rg} 1$ and ginsenoside $\mathrm{Rb} 1$ are major compounds of KRG. Therefore, these results suggest that KRG may inhibit cardiac injury due to prevention of ROS generation by ISO. In conclusion, the results may further lend to the understanding of the beneficial effects of KRG against cardiac infarction induced by ISO.

\section{ACKNOWLEDGEMENTS}

This work was supported by a 2011 grant from the Korean Society of Ginseng funded by Korea Ginseng Corporation.

\section{REFERENCES}

1. Kumar JS, Menon VP. Changes in levels of lipid peroxides and activity of superoxide dismutase and catalase in diabetes associated with myocardial infarction. Indian J Exp Biol 1992;30:122-127.

2. Aronow WS. Epidemiology, pathophysiology, prognosis, and treatment of systolic and diastolic heart failure. Cardiol Rev 2006;14:108-124.

3. Lopez AD, Murray CC. The global burden of disease, 1990-2020. Nat Med 1998;4:1241-1243.
4. Cai Q, Rahn RO, Zhang R. Dietary flavonoids, quercetin, luteolin and genistein, reduce oxidative DNA damage and lipid peroxidation and quench free radicals. Cancer Lett 1997;119:99-107.

5. Dikshit M, Van Oosten MH, de Graff S, Srimal RC. Free radical scavenger mechanisms in experimentally induced ischemia in the rabbit heart and protective effect of verapamil. Arch Int Pharmacodyn Ther 1992;318:55-65.

6. Nakamura T, Nishi H, Kokusenya Y, Hirota K, Miura Y. Mechanism of antioxidative activity of fluvastatin-determination of the active position. Chem Pharm Bull (Tokyo) 2000;48:235-237.

7. Rathore N, John S, Kale M, Bhatnagar D. Lipid peroxidation and antioxidant enzymes in isoproterenol induced oxidative stress in rat tissues. Pharmacol Res 1998;38:297303.

8. Srivastava S, Chandrasekar B, Gu Y, Luo J, Hamid T, Hill BG, Prabhu SD. Downregulation of CuZn-superoxide dismutase contributes to beta-adrenergic receptor-mediated oxidative stress in the heart. Cardiovasc Res 2007;74:445455 .

9. Liu Z, Li Y, Li X, Ruan CC, Wang LJ, Sun GZ. The effects of dynamic changes of malonyl ginsenosides on evaluation and quality control of Panax ginseng C.A. Meyer. J Pharm Biomed Anal 2012;64-65:56-63.

10. Yamabe N, Song KI, Lee W, Han IH, Lee JH, Ham J, Kim SN, Park JH, Kang KS. Chemical and free radical-scavenging activity changes of ginsenoside Re by maillard reaction and its possible use as a renoprotective agent. J Ginseng Res 2012;36:256-262.

11. Ribeiro DA, Buttros JB, Oshima CT, Bergamaschi CT, Campos RR. Ascorbic acid prevents acute myocardial infarction induced by isoproterenol in rats: role of inducible nitric oxide synthase production. J Mol Histol 2009;40:99-105.

12. Ramesh CV, Malarvannan P, Jayakumar R, Jayasundar S, Puvanakrishnan R. Effect of a novel tetrapeptide derivative in a model of isoproterenol induced myocardial necrosis. Mol Cell Biochem 1998;187:173-182.

13. Lum G, Gambino SR. A comparison of serum versus heparinized plasma for routine chemistry tests. Am J Clin Pathol 1974;61:108-113.

14. Reitman S, Frankel S. A colorimetric method for the determination of serum glutamic oxalacetic and glutamic pyruvic transaminases. Am J Clin Pathol 1957;28:56-63.

15. Rosalki SB. An improved procedure for serum creatine phosphokinase determination. J Lab Clin Med 1967;69:696-705.

16. Misra HP, Fridovich I. The role of superoxide anion in the autoxidation of epinephrine and a simple assay for super- 
oxide dismutase. J Biol Chem 1972;247:3170-3175.

17. Aebi H. Catalase in vitro. Methods Enzymol 1984;105: 121-126.

18. Rotruck JT, Pope AL, Ganther HE, Swanson AB, Hafeman DG, Hoekstra WG. Selenium: biochemical role as a component of glutathione peroxidase. Science 1973; 179:588-590.

19. Zhou R, Xu Q, Zheng P, Yan L, Zheng J, Dai G. Cardioprotective effect of fluvastatin on isoproterenolinduced myocardial infarction in rat. Eur J Pharmacol 2008;586:244-250.

20. Yuan HD, Quan HY, Jung MS, Kim SJ, Huang B, Kim DY, Chung SH. Anti-diabetic effect of pectinase-processed ginseng radix (GINST) in high fat diet-fed ICR mice. J Ginseng Res 2011;35:308-314.

21. Yang Y, Hu SJ, Li L, Chen GP. Cardioprotection by polysaccharide sulfate against ischemia/reperfusion injury in isolated rat hearts. Acta Pharmacol Sin 2009;30:54-60.

22. Mullane KM, Kraemer R, Smith B. Myeloperoxidase activity as a quantitative assessment of neutrophil infiltration into ischemic myocardium. J Pharmacol Methods 1985;14:157-167.

23. Cho ES, Ryu SY, Jung JY, Park BK, Son HY. Effects of red ginseng extract on zearalenone induced spermatogenesis impairment in rat. J Ginseng Res 2011;35:294-300.

24. Karthick M, Stanely Mainzen Prince P. Preventive effect of rutin, a bioflavonoid, on lipid peroxides and antioxidants in isoproterenol-induced myocardial infarction in rats. J Pharm Pharmacol 2006;58:701-707.

25. Upaganlawar A, Gandhi C, Balaraman R. Effect of green tea and vitamin $\mathrm{E}$ combination in isoproterenol induced myocardial infarction in rats. Plant Foods Hum Nutr 2009;64:75-80.

26. Laine GA, Allen SJ. Left ventricular myocardial edema. Lymph flow, interstitial fibrosis, and cardiac function. Circ Res 1991;68:1713-1721.

27. Holland RP, Brooks H. TQ-ST segment mapping: critical review and analysis of current concepts. Am J Cardiol 1977;40:110-129.

28. Gupta SK, Mohanty I, Talwar KK, Dinda A, Joshi S, Bansal P, Saxena A, Arya DS. Cardioprotection from ischemia and reperfusion injury by Withania somnifera: a hemodynamic, biochemical and histopathological assessment. Mol Cell Biochem 2004;260:39-47.

29. Sawyer DB, Siwik DA, Xiao L, Pimentel DR, Singh K, Colucci WS. Role of oxidative stress in myocardial hypertrophy and failure. J Mol Cell Cardiol 2002;34:379388.
30. Kim YS, Kim YH, Noh JR, Cho ES, Park JH, Son HY. Protective effect of Korean red ginseng against aflatoxin B1-induced hepatotoxicity in rat. J Ginseng Res 2011;35:243-349.

31. Karthikeyan K, Bai BR, Devaraj SN. Cardioprotective effect of grape seed proanthocyanidins on isoproterenol-induced myocardial injury in rats. Int J Cardiol 2007;115:326-333.

32. Zhou B, Wu LJ, Li LH, Tashiro S, Onodera S, Uchiumi F, Ikejima T. Silibinin protects against isoproterenolinduced rat cardiac myocyte injury through mitochondrial pathway after up-regulation of SIRT1. J Pharmacol Sci 2006;102:387-395.

33. Ramani R, Mathier M, Wang P, Gibson G, Togel S, Dawson J, Bauer A, Alber S, Watkins SC, McTiernan CF et al. Inhibition of tumor necrosis factor receptor-1-mediated pathways has beneficial effects in a murine model of postischemic remodeling. Am J Physiol Heart Circ Physiol 2004;287:H1369-H1377.

34. Patel V, Upaganlawar A, Zalawadia R, Balaraman R. Cardioprotective effect of melatonin against isoproterenol induced myocardial infarction in rats: a biochemical, electrocardiographic and histoarchitectural evaluation. Eur J Pharmacol 2010;644:160-168.

35. Xie JT, Shao ZH, Vanden Hoek TL, Chang WT, Li J, Mehendale S, Wang CZ, Hsu CW, Becker LB, Yin JJ et al. Antioxidant effects of ginsenoside Re in cardiomyocytes. Eur J Pharmacol 2006;532:201-207.

36. Deng HL, Zhang JT. Anti-lipid peroxilative effect of ginsenoside Rb1 and Rg1. Chin Med J (Engl) 1991;104:395398.

37. Lim JH, Wen TC, Matsuda S, Tanaka J, Maeda N, Peng H, Aburaya J, Ishihara K, Sakanaka M. Protection of ischemic hippocampal neurons by ginsenoside Rb1, a main ingredient of ginseng root. Neurosci Res 1997;28:191200.

38. Tian J, Fu F, Geng M, Jiang Y, Yang J, Jiang W, Wang C, Liu K. Neuroprotective effect of 20(S)-ginsenoside Rg3 on cerebral ischemia in rats. Neurosci Lett 2005;374:9297.

39. Lu JM, Yao Q, Chen C. Ginseng compounds: an update on their molecular mechanisms and medical applications. Curr Vasc Pharmacol 2009; 7:293-302.

40. Saw CL, Yang AY, Cheng DC, Boyanapalli SS, Su ZY, Khor TO, Gao S, Wang J, Jiang ZH, Kong AN. Pharmacodynamics of ginsenosides: antioxidant activities, activation of Nrf2, and potential synergistic effects of combinations. Chem Res Toxicol 2012;25:1574-1580. 